43-44 | 2013

Le pastoralisme en Haute-Asie : la raison nomade dans l'étau des modernisations

\title{
Social and economic aspects of the uses of animal wool and hair in western Mongolia
}

Les aspects sociaux et économiques de l'utilisation de la laine et des poils provenant d'animaux domestiques dans l'ouest de la Mongolie

Anna O. Portisch

\section{OpenEdition}

Journals

Édition électronique

URL : https://journals.openedition.org/emscat/2080

DOI : 10.4000/emscat.2080

ISSN : 2101-0013

Éditeur

Centre d'Etudes Mongoles \& Sibériennes / École Pratique des Hautes Études

Référence électronique

Anna O. Portisch, « Social and economic aspects of the uses of animal wool and hair in western Mongolia », Études mongoles et sibériennes, centrasiatiques et tibétaines [En ligne], 43-44 | 2013, mis en ligne le 20 septembre 2013, consulté le 13 juillet 2021. URL : http://journals.openedition.org/emscat/ 2080 ; DOI : https://doi.org/10.4000/emscat.2080

Ce document a été généré automatiquement le 13 juillet 2021.

(c) Tous droits réservés 


\title{
Social and economic aspects of the uses of animal wool and hair in western Mongolia
}

\author{
Les aspects sociaux et économiques de l'utilisation de la laine et des poils \\ provenant d'animaux domestiques dans l'ouest de la Mongolie
}

Anna O. Portisch

\section{Introduction}

1 This article considers social and economic uses of wool and hair derived from domestic animals amongst the Kazakh population living in the western-most Mongolian province, Bayan-Ölgii. This province is mainly populated by Kazakhs, who form the country's largest minority and are concentrated in the western provinces of the country (NSO 2001, p. 51). In Bayan-ölgii, most Kazakhs live in log cabins or mud brick houses from September to June, and during the summer months they live in yurts (Kz. kiiz üi, literally meaning 'felt house') (see Kämälashuly 2005). Many move several times a year with their herds between seasonal settlements. Most people in this province are dependent, either directly or indirectly through family networks, on domestic animals for their livelihood. Sheep, goats, horses, cattle, yaks or hybrids ${ }^{1}$ and camels provide meat and dairy products, which together with flour are the staples of the Kazakh diet. The herds also yield wool and hair, which are used in the everyday production of textiles and artefacts for the home.

2 Felt is made from lamb's and sheep's wool and used in the production of a variety of artefacts, such as carpets, lining for winter boots, and the cover of the yurt itself. Sheep's wool is also spun and used for knitting ${ }^{2}$ and to produce colourful woven straps for the yurt. Camel's wool is spun to make yarn and a strong thread for the assembly of felt carpets. Cattle and horse hair is braided to make rope for the yurt ${ }^{3}$. Such artefacts 
made at the household level are predominantly used in people's own homes and in wedding-related gift exchanges.

Some animal products are also sold. For instance, goats are 'combed' in late spring and early summer, and the hair is sold at the market in the province's main urban centre, ölgii, for the eventual production of cashmere products. Sheep and lamb skins are occasionally sold when market conditions are favourable. Some Kazakh women also produce felt and embroidered artefacts for sale to tourists and through nongovernmental organisations (NGOs) or charity-run projects operating in the province.

Most adults, however, remember the period of Soviet-backed state socialism. This period (particularly from the establishment of the collectives in the 1950s to the dissolution of the Soviet Union in 1991) has been described as characterised by a particular 'sociotechnical system' in virtue of the way in which it integrated economic and domestic activities with techniques, material objects and the social coordination of labour (Sneath 2004, p. 170, 1999, p. 224). By contrast, the period from the early 1990s, or 'the age of the market', has been described as increasingly 'atomized' and 'demechanised' (Sneath 2004, p. 163) and as characterised by a general move towards subsistence-based livelihood strategies (Finke 2004, p. 403). Whilst the same domestic animals form the basis of people's livelihoods, and the same raw materials are used to produce artefacts, these practices now take place as part of a different economic environment.

5 This article therefore begins by framing Kazakh households' economic and domestic practices in the context of the recent past. It briefly outlines the framework for economic activity during the period leading up to the dissolution of the Soviet Union, and some of the major changes that have affected people's livelihoods over the past twenty years. The article then focuses on the practices in a household in Ulaanhus district (sum) in the early 2000 s. It considers the detail of domestic uses of wool and hair, the social life around such uses and production routines, and a variety of economic strategies with these products. In this way, the article seeks to show how the uses of animal products are practices which reflect the economic and social situation of the household as well as wider economic and political processes.

\section{Background}

6 During the period of Soviet-backed state socialism, animal products including meat and dairy products, skins, fleeces and horns were the property of the collectives (Mg. negdel, Kz. birlestik) and found markets mainly in countries belonging to the Council for Mutual Economic Assistance (CMEA or Comecon). In western Mongolia, each district (sum) coincided with a collective ( $c f$. Sneath 2004, p. 163). The collectives were thus economic and territorial units and constituted the legal and judiciary framework for economic activity (Finke 2003b, p. 260). In addition to employing mobile pastoralists, the collectives employed people in a range of jobs. The Ulaanhus collective in Bayan-ölgii province, for instance, employed some 200 persons in jobs including agronomists, veterinary surgeons, mechanics, drivers, supervisors, accountants and cleaners.

7 A proportion of the members of the collectives were mobile pastoralists who lived in settlements at varying distances from the district centre and moved in accordance with herd composition and size, climate and other considerations. Households were assigned livestock and had to deliver certain quantities of animal products at fixed prices (Finke 
2003a, p. 204) in return for which they received a regular income as well as everyday items such as flour and salt. This incorporation of individual households into this macro-economic structure has in this regard been termed a "quasi-barter system" (ibid., p. 204 ; see also Sneath 2002).

8 As a former member of the Ulaanhus collective explained, under this system, "nothing was wasted" (at a local level) ; all parts of the animal were collected. Dairy products and meat, wool or hides, as well as horns were collected and processed in or distributed from the district and province centres. Nevertheless, the system had its own informal level of negotiation and flexibility (see also Finke 2003b, pp. 250-251). One story told was of an accountant working for a collective, who on one occasion agreed to 'neglect' to record the birth of new calves in a remote rural household responsible for herding cows, thus allowing the household to increase its private holdings against a small 'gift'.

Animals were divided into herds according to species and sex. Typically a herd of goats or sheep consisted of 500-600 animals (Finke 2003a, p. 204), whereas herds of large domestic animals such as cattle, horses or camels consisted of some 100-200 animals (Finke 2003b, p. 251). People in Ulaanhus described this system as one in which members of the collectives had "shared ownership" of the bulk of the livestock, while individual households were allowed to keep up to 75 heads of livestock of their own to cover domestic needs of meat, dairy products and wool (ibid., p. 251). Domestic needs, met from these privately owned animals, generally provided households with sufficient meat, dairy and wool, and processing of animal products for household consumption thus continued during the state socialist period, from cheese to felt making.

10 The dissolution of the Soviet Union and the ensuing economic 'shock therapy' transition of the early 1990s plunged the country as a whole into a severe macroeconomic crisis. The CMEA, since Mongolia's joining in 1962, had contributed an average of the equivalent of one billion US dollars per annum to the Mongolian economy, and provided approximately 30 percent of Mongolia's gross national product in the form of grants and low interest loans (Badarch et al. 2003, p. 7). By 1989, over 80 percent of imports were from the USSR (Sneath 2003, p. 41). During the 1980s, CMEA and other centrally-planned economies absorbed over 90 percent of Mongolia's exports (Badarch et al. 2003, p. 7, Goyal 1999, p. 634). Within this economic system, production quotas were delivered by the collectives for processing, internal redistribution or export by state agencies, including livestock and meat for the USSR's Siberian industries and towns (Goyal 1999, p. 634) as well as minerals and gold (Finke 2003a, p. 220 ; see Kerven et al. 2002 on the Central Asian economies).

11 In western Mongolia, until 1990, approximately ten percent of Mongolia's total exports and eight percent of its imports passed through Bayan-ölgii's trans-shipment base in Tsagaan Nuur near Mongolia's northern border, via the road between ölgii and the Gorno-Altaisk area in the USSR (Sanders 1993, p. 189). In the early 1990s, this flow of trade ceased with the temporary closure of the border between Mongolia and Russia. Trade later resumed when the border was reopened, but only in the form of small-scale private initiatives. Villages near the border now serve as trading points where local Kazakh traders do not need a visa or international passport. Traders buy everyday goods like flour, salt and tea as well as luxury goods like chocolate and vodka, which they sell in Ölgii and other towns in the province (see Lacaze 2005). Some Kazakh hunters also bring wolf, fox and other furs to sell at these border trading posts and some traders bring animal products such as lamb skins. Such practices are directly 
affected by rising inflation and the cost of petrol, however. In 2005, for instance, there were reports that traders no longer found such trips profitable given the rising cost of petrol $^{4}$ and the falling price offered by Russian traders (cf. Kerven et al. 2002).

Until 1990, industries in Bayan-ölgii had included factories and workshops for processing raw materials from domestic animals, including a wool-processing factory and carpet making workshop. Such factories and workshops were gradually privatised in the early 1990s. Yet, in the absence of the 'sociotechnical system' that had facilitated economic activity until the 1990s, they eventually proved financially unviable and closed. The local economic situation mirrored a national-level economic decline.

With the dissolution of the Soviet Union and subsequently the CMEA in 1991, Soviet economic assistance ceased as did trade with nearly all of Mongolia's former trade partners (Badarch et al. 2003, p. 8). Over a ten-year period, the number of persons living below the poverty line increased from less than one percent (1989) to 33 percent (1998) (Sneath 2004, p. 162). As unemployment rose, the currency and savings and pension funds were devalued, and subsidies on essential goods as well as for education and healthcare were reduced or eliminated (see Badarch et al. 2003, p. 8), the country saw an increase in the share of the population engaged in mobile pastoralism as a means of survival.

The state farms and collectives were dissolved in the early 1990s. In Bayan-ölgii, the property of the Ulaanhus collective, including animals, vehicles and other machinery, was distributed amongst its former members. As Sneath argues, the privatisation of the collectives broke up "... the concentrated herd ownership, the large-scale movement systems, and specialist support mechanisms that the collectives had organized" (2004, p. 162). These changes of the early 1990s rendered individual households far more vulnerable in what emerged as an "atomized and demechanised pastoral sector" (ibid., p. 163, Finke 2004, p. 401).

15 At a national level, the dissolution of the collective farms made a quarter of a million former collective and state workers directly dependent on small holdings of livestock (Sneath 2004, p. 163). This almost trebled the number of workers directly reliant on pastoralism for their livelihood, from less than 18 percent of the national workforce in 1989 to 50 percent in 1998 (ibid., p. 162). Thus, at the same time as a greater proportion of the population became dependent on small holdings of livestock, the economy became increasingly subsistence-based and there was a relative withdrawal of the pastoral sector from the market (see Finke 2004, p. 403) . $^{5}$

As a consequence, the size of herds belonging to individual households changed. Moreover, there was a move towards multi-species and older herds, said to be more resistant to diseases and harsh weather conditions (see Finke 2004, p. 401). There was also a change in livestock composition at a national level : goats were preferred since raw cashmere became an important source of cash income to herders (Finke 2004, p. 401, Kerven et al. 2002, pp. 29-30, El Benni \& Reviron 2009, pp. 19-25).

17 In Bayan-Ölgii today, many people are reliant on relatively small herds of sheep and goats (see NSO 2008, pp. 52-53), often considered inadequate for sustaining a household in the long term. In order to sustain them through the winter, most households slaughter approximately a dozen sheep or goats as well as one or two large domestic animals (cattle or horses) in the winter slaughter. This takes place in November, when the animals retain reserves of fat from the summer, but the temperature has dropped sufficiently for the meat to freeze and keep throughout the winter in an outside shed. 
In addition, throughout the summer and autumn, at least one small animal is slaughtered every 10-14 days for domestic consumption. The number of new births, of course, has to be equal to or more than the number of animals consumed in any one year.

Many families in western Mongolia have been adversely affected by repeated unusually harsh winters (Mg. zud, Kz. zhud), which have negatively affected herd sizes. The winters of 1999-2000 and 2000-2001, for instance, saw a total loss of six million livestock across the country (Sneath 2004, p. 163). Unusually harsh weather conditions recurred in the winter of 2004-2005 and most recently in 2009-2010. Losses of grown animals occur during the winter months, when the animals have difficulty getting to the pasture due to snow fall, or because pasture is simply not adequate in a given winter settlement area, a problem perpetuated by a preceding dry summer. The most significant losses, however, usually only become apparent in spring and early summer when it is known how many grown animals, undernourished from the long winter, have been able to withstand the harsh spring weather; and it will then be known how many lambs or kids were born live and survived into summer. Recent testimonies from Bayan-Ölgii indicate that this is an increasingly frequent occurrence: "People are struggling this year [2010] because of the consequences of the ... past winter. They say the past winter has been the worst in 50 years and $25 \%$ of animals died. Now it is the middle of August [and] some families don't have dairy products and are having black tea in the middle of summer ... [They have] no living resources ..." (Bulbul Ustav, email correspondence, 10 August 2010). Summer is usually the time of year when dairy products abound. Tea is the only drink Kazakhs have; it is drunk at least five times a day and is always made with fresh cow's milk (and salt); having black tea is a sign of poverty.

19 Such losses affect the amount of animal products people have at their disposal, and thereby also their food security. It affects them on a domestic level, in terms of whether they will have enough wool and hair to renew the felt carpets they use in their home and whether they are able to repair or make new felt covers for their summertime dwelling, the yurt. It affects their social life in terms of whether they are able to contribute to the weddings of relatives with gifts of carpets and other artefacts. It affects their seasonal migration choices, as with only few animals there may not be any need to move to other pasture areas, and there may also not be the funds to pay for the petrol required to undertake such a move.

Until 1990, mechanisms were in place to support members of the collectives through such climatic conditions, for instance through the provision of veterinary services, seasonal and emergency fodder, ice for families in distant settlements with no access to water or snow, transport between seasonal settlements and livestock insurance (see Siura \& Swift 2002). Herding families now privately own their animals and have no form of government support to help them get through such climatic conditions.

\section{An Ulaanhus household}

Several times during my fieldwork with a Kazakh family in the winter of 2004-2005, we saw Bolat ${ }^{6}$, our neighbour, walking slowly towards the house dragging a heavy load. Several of the family's goats perished during the zhud and he brought back the animals in order to cut the hair, which could be sold later in spring at the market in ölgii when 
buyers from the capital came to the province. Ordinarily the goats were combed in late spring (with a steel comb with hooked 'fingers'), but under these circumstances the hair could simply be cut.

Bolat lived with his wife Aizhan and three of their children in a mud brick winter house in a small village composed of some 200 households : scattered mud brick houses and $\log$ cabins, situated an hour's drive from the district (sum) centre. Their eldest son was at college in Ölgii and living with relatives there. Bolat worked at the local Eight Year School ${ }^{7}$ as a janitor, his main responsibility being to light and maintain the coal powered heating system at the school and the attached children's dormitory. This had previously been a stable and adequately paid position, but over the past fifteen years the salary had not kept pace with inflation and it had been paid at increasingly irregular intervals. Even the work itself had become unpredictable since the school did not always have adequate supplies of coal.

The family had a mixed herd of 40 goats and sheep, four hybrids and two horses. The herd provided milk and meat for daily consumption. Flour, salt, tea and other essential goods were bought in bulk every few months at the market in the province centre. Bolat's wife Aizhan, educated in the Soviet Union as an engineer, had not found work locally on returning to Bayan-Ölgii in the late 1980s, and the bulk of the family's expenses were met from Bolat's salary. In 2008, however, Aizhan became a member of a small, newly established craft co-operative with a dozen members, set up with the help of a North American charity. She began to make a variety of embroidered artefacts (bags, pillow covers, table runners, such as the one in photo 1) sold to tourists and via the internet to western consumers. The income the co-operative gained from this work was highly seasonal, summertime tourists being the main buyers. However, with financial assistance and low-interest loans from another NGO, the members of the cooperative were at the time able to get a monthly salary of $80000 \mathrm{~F}$ throughout the year, equivalent to that of a school teacher. Sales made during the summer were to be used to repay the loan taken out to cover the members' salaries. 
Photo 1. An embroidered handbag, made by a member of a crafts cooperative

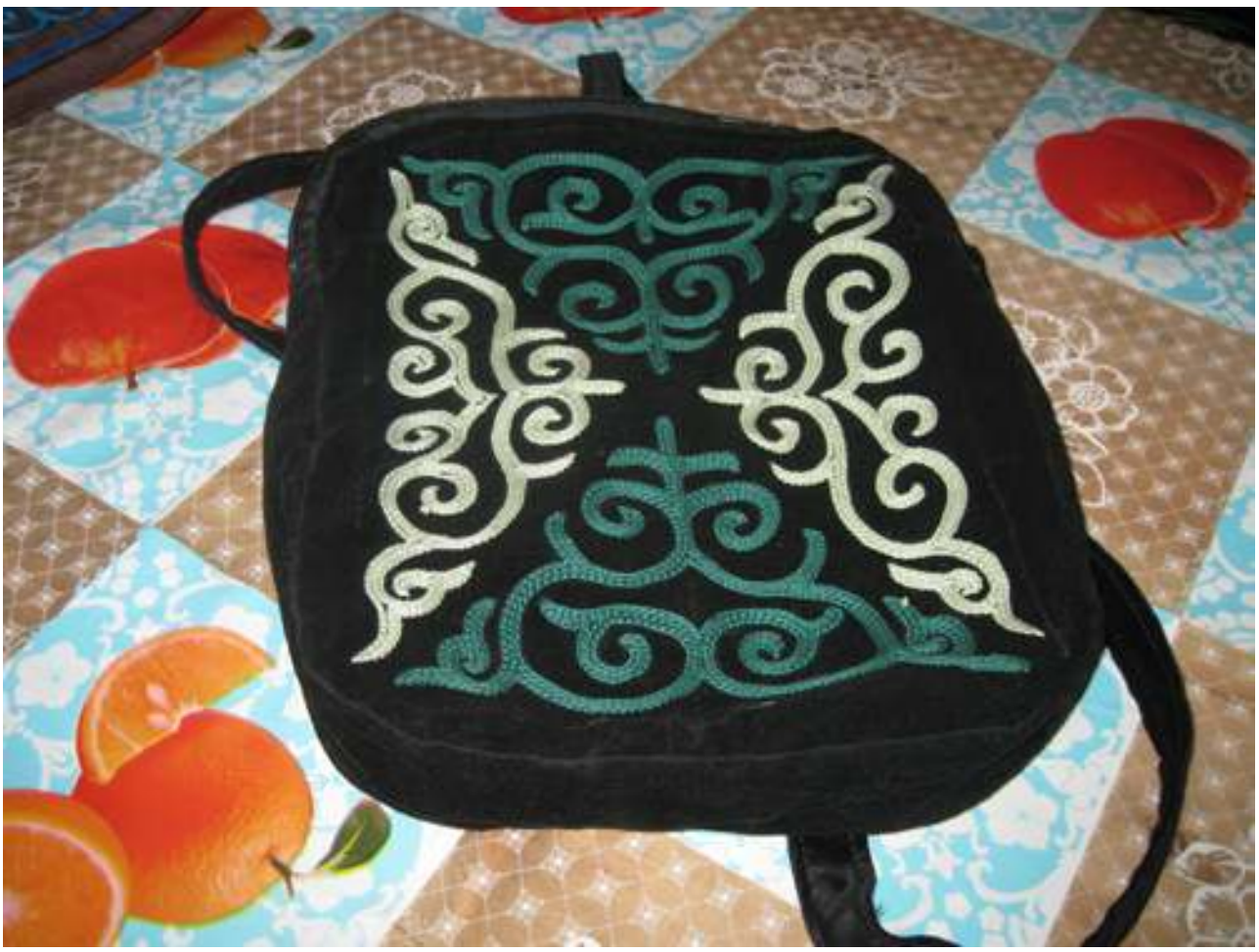

Photo by Anna Portisch

local standards her salary was relatively high. Yet to put this into context, a bag of 50 kilos of flour (one such bag is consumed every month in a household of six-seven persons) cost $13000 \%$ in 2005. In 2008, the price had gone up to 44000 . This increase was mainly due to inflation and the rising cost of petrol (for transportation to markets in Bayan-ölgii). From the perspective of time spent, the cost of involvement, and the share Aizhan received, her membership of the co-operative was a unique and positive opportunity, she felt. Nevertheless, the income barely covered the cost of the family's living expenses. In contrast, many other charity or NGO run crafts projects in the area were 'commission based' ; those involved made money only from sales of artefacts they had made.

Like many families in Bayan-ölgii, Bolat and Aizhan no longer moved to a separate summer location (Kz. zhailau) ${ }^{8}$. The pasture around the village was sufficient and their relatively small herd did not require such a move. Moreover, the substantial cost was difficult to cover (enlisting the help of a relative in possession of or with access to a truck and paying for the petrol). Moreover, usually at least two or three households will set up their summertime yurts together forming a summer settlement (Kz. auyl), but the relatives with whom Bolat and Aizhan had moved in the past, had also chosen to remain close to their winter house for practical and financial reasons. Thus the summer months were spent only twenty metres from their winter mud-brick house, which was used for storing some belongings and furniture, and the relatively cool shed was used to hang freshly cut and salted meat, just as in winter.

26

Aizhan and Bolat's daughter, Gülnara, was 12 and in her sixth year at the local school. she and her brothers learnt the steps involved in taking care of the animals and 
processing the raw materials by participating with their parents and siblings in their daily routine. Aizhan and Gülnara milked the hybrids, sheep and goats and prepared dairy products in summer; Gülnara's brothers took the animals to pasture before school and gathered them after school (the animals would not graze further than a few kilometres from the house); her father and brothers sheared the sheep; she and her mother sorted the wool and processed it; her father slaughtered the animals; and she and her mother washed, prepared and filled the intestines and cut and salted the meat. A gendered division of household tasks pertained, and did so in most Kazakh households in Bayan-Ölgii, whereby tasks falling to men often took place out of doors (herding and shearing the animals, collecting firewood and suchlike), whereas tasks pertaining to women were centred around the home (cooking, cleaning, caring for the children, decorating the home and suchlike).

This was, however, not a formal social rule nor was it strictly upheld. If individuals had a preference or a particular aptitude for a certain task, they might choose to ignore this loosely defined division of household tasks. Bolat often cooked the family's meals, slowly and neatly dicing the meat. Gülnara and her mother went far afield in the valley collecting dried dung in old flour sacks, used for fuel in summer. A few men helped their wives in quilting carpets and spinning wool. A man might be made fun of for such 'feminine skills', or be pushed aside by visiting female relatives in the kitchen area. In this way, it was often practices like joking or gossiping that worked to delineate gendered roles. Similarly, the children learnt a variety of social expectations and conventions, not by directly instructive means, but by participating with other family members in the daily routine, helping their elders where requested, and understanding others' reactions to their own actions and attitudes.

Household tasks were perhaps more clearly divided according to age group and individual status. Households in Bayan-Ölgii were often composed of three or more generations. Elderly women and men would ordinarily be held in high respect and often oversaw household tasks and provided instructions. In this context, children would assist their parents in the general running of the household, and young girls like Gülnara often carried out household tasks like collecting water and dung, lighting the fire, cooking and cleaning. The sense in which older family members were held in respect and taught their children to carry out important functions in the household could thus be seen in the way everyday tasks were organised. Collaborative tasks, such as preparing wool and making felt, also indicated a social organisation of household tasks defined loosely along age and gender lines.

\section{Domestic uses of wool and hair}

Bolat and his sons sheared the family's sheep and lambs in late summer (the technique is shown in photo 2). They worked together, shearing one or two animals per day. The wool was collected, separated according to quality and colour and kept in the shed. The grown sheep could be sheared twice: once in June and once in late August, a practice said to be a legacy from the state socialist period (cf. Finke 2003a, p. 212). The first shearing gave a coarse wool that was full of the dirt and dust of the previous autumn, winter and spring. This wool would need to be treated for longer to get rid of the dirt and separate the fibres, but could be used to make felt for the cover of the yurt, for instance (photo 3). The wool from the August shearing was shorter, softer and cleaner, 
making it more suitable for finer projects such as felt carpets (Kz. sürmaq). The wool from lambs born the same year (from January and into the spring) was of the finest quality and was similarly used for carpets, unless the lamb skins were used for lining waist coats or winter coats.

Photo 2. Shearing sheep (Dayan, Ulaanhus)

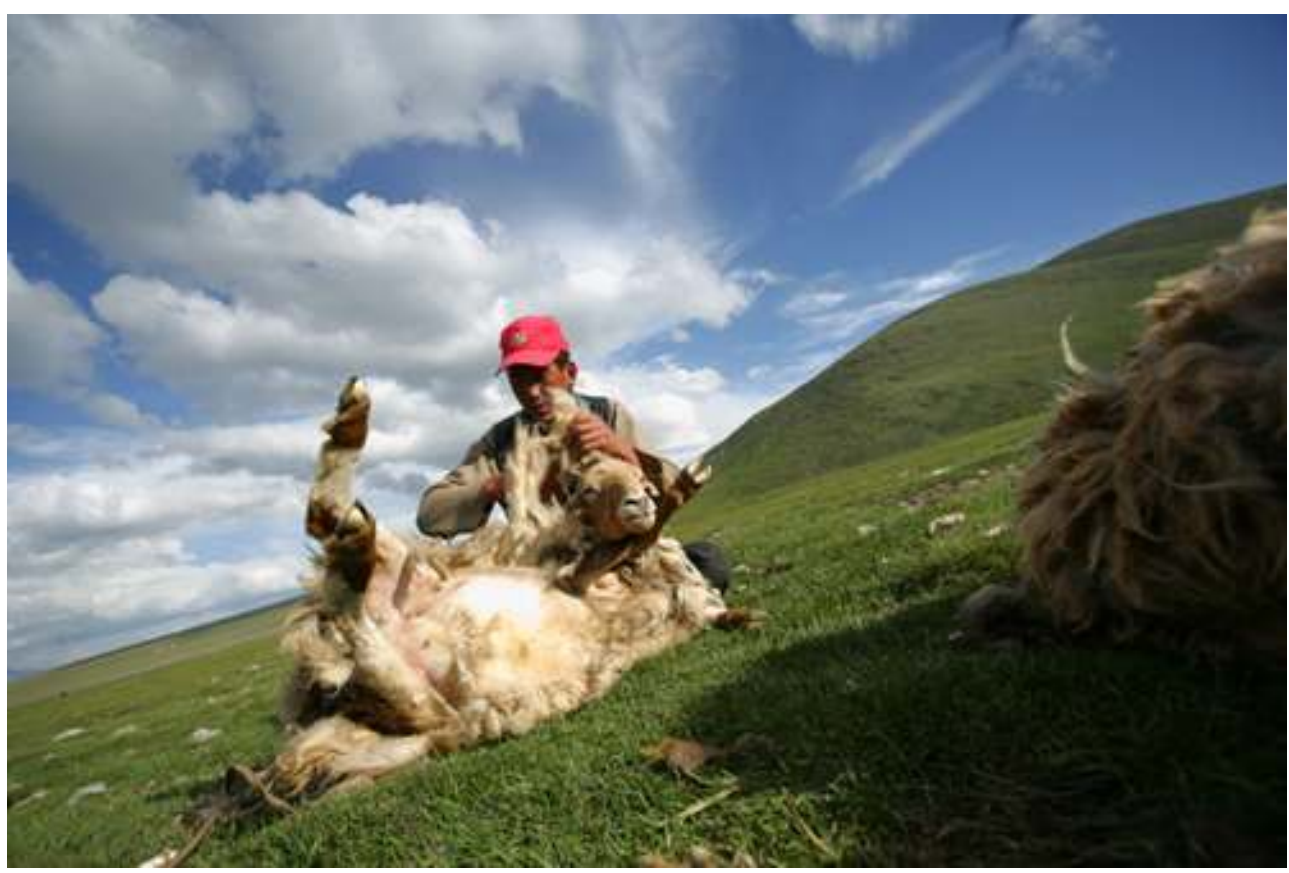

Photo by Antoine de Changy

Photo 3. Repairing the felt covers of the summertime yurt

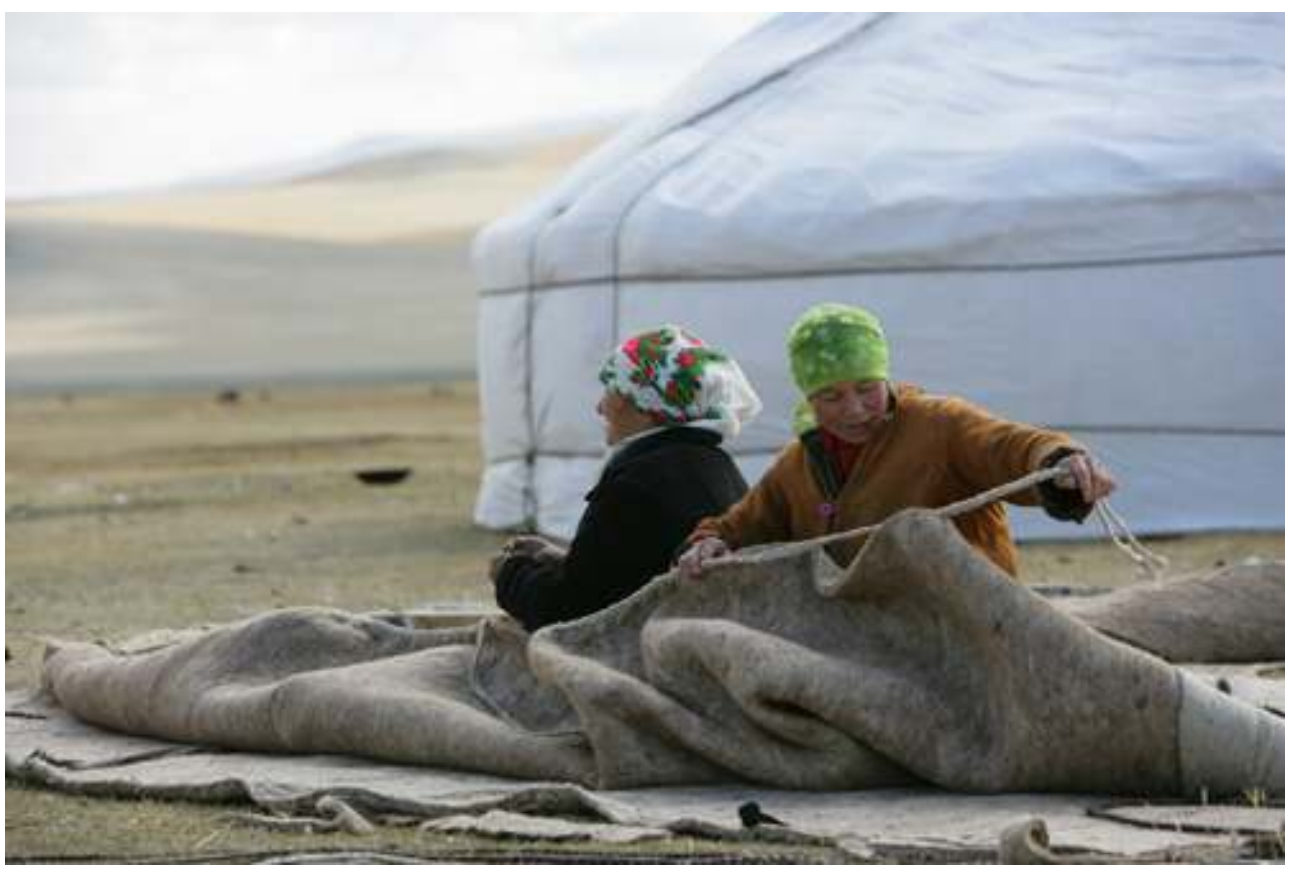

Photo by Antoine de Changy 
30

enough wool had been gathered, it was prepared for spinning (Kz. zhün iru) or felt making (Kz. kiiz zhazau). In August 2004, Aizhan and Bolat had not gathered enough wool to make felt, but Aizhan cleaned, carded and spun the wool they had gathered and used this yarn together with felt, which she bought from a neighbouring household, and bought fabric, to make two felt carpets in the course of the winter. However, in the late summer, a few households in the village were busy carding and beating wool and rolling felt, and Aizhan and Gülnara went to help, just as others helped them with tasks that demanded several people's participation. The rhythmical sound of beating wool can often be heard several kilometres away on a still summer's day, and is easily recognised by someone who has participated in the activity, and often prompts neighbours to go and help with the task and exchange the latest gossip.

Hand carding or beating the wool (photos 4 \& 5) rids the wool of dust and dirt, separates the fibres and gives the wool a fluffy quality (carders in the shape of brushes or sharp toothed instruments are not generally used in Bayan-Ölgii). In one household on the outskirts of the village, a make-shift yurt (Kz. qos) had been set up for storage purposes and to carry out various household tasks, such as beating lamb's wool. A heap of wool was laid on top of an old sheep skin. Several girls had been enlisted to help with the task. They kneeled in a circle and beat the wool with willow sticks. This is dusty, hot and tiring work that requires each participant to maintain the same rhythm. The work was carried out inside the qos to avoid tufts of wool from flying off, as it was a relatively windy day. The girls were quickly out of breath but joked and sang popular Kazakh and western pop songs to hold the rhythm.

Photo 4. Hand carding lamb's wool inside the yurt

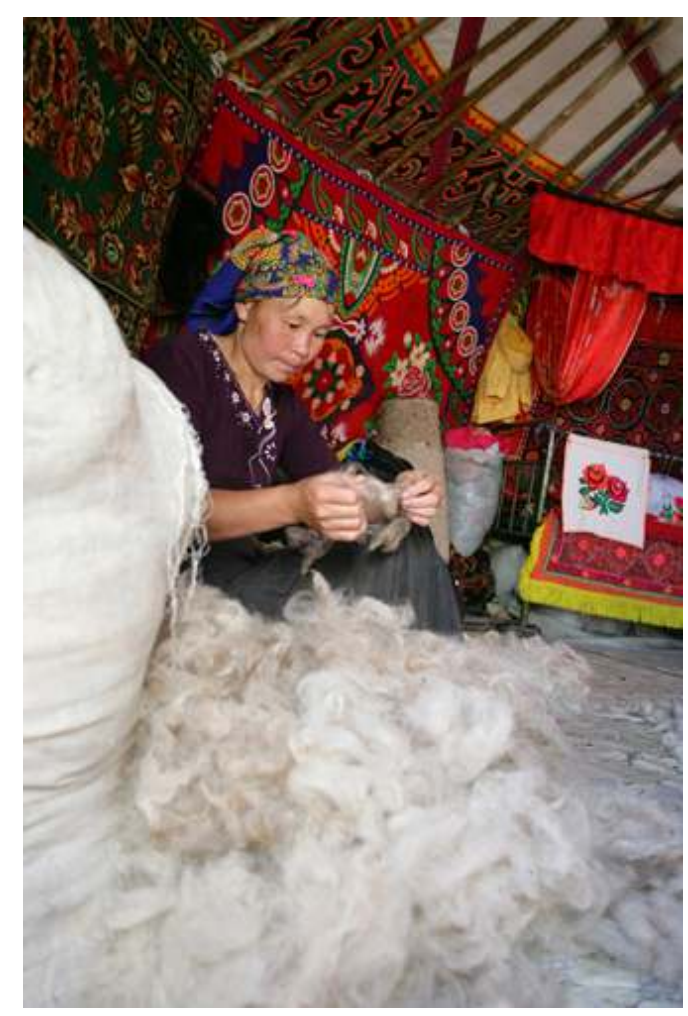

Photo by Antoine de Changy

Études mongoles et sibériennes, centrasiatiques et tibétaines, 43-44 | 2013 
Photo 5. Women beating lamb's wool in preparation for making felt

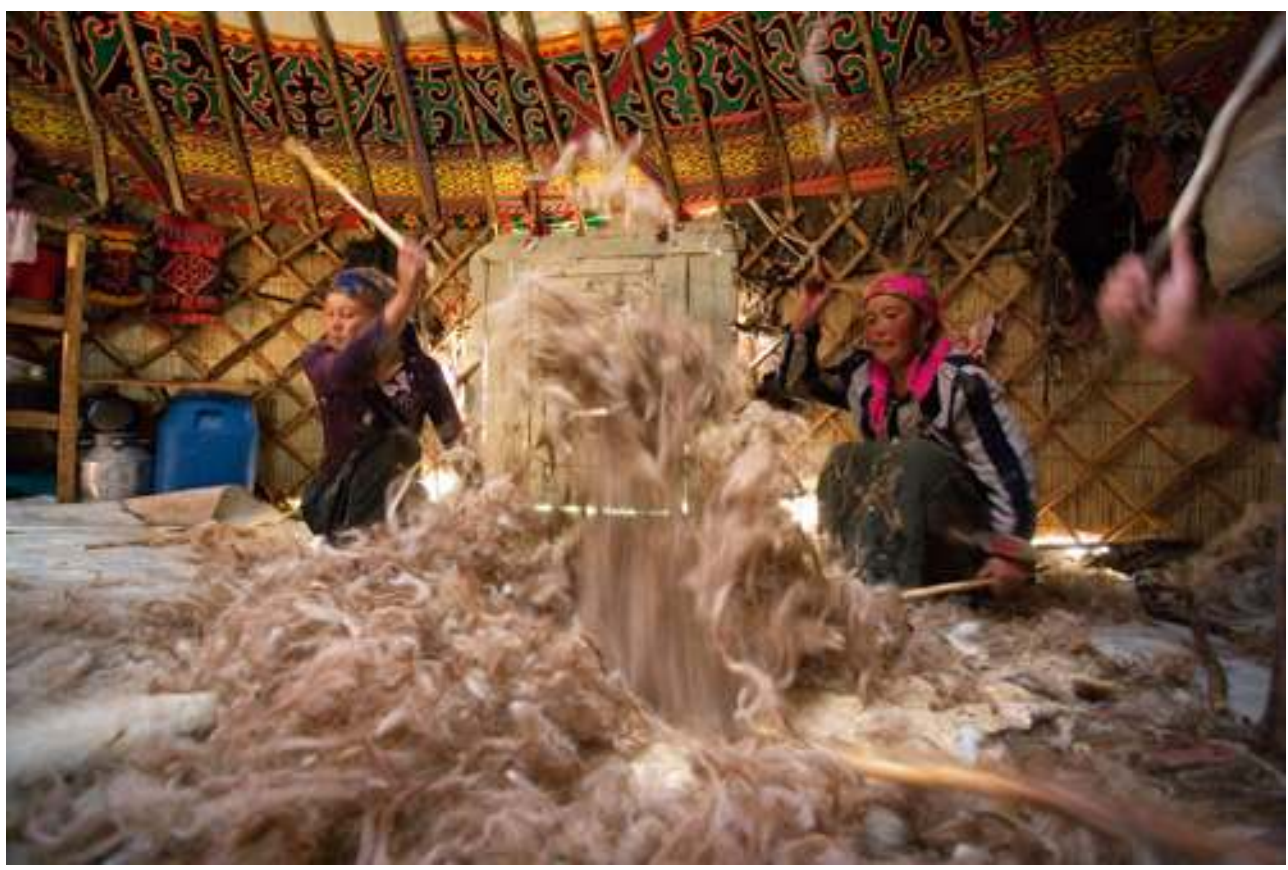

Photo by Antoine de Changy

32 After a short tea break, the wool was distributed on top of a reed mat (Kz. shi) in several even layers lying perpendicular to one another. This was done under the supervision of the most senior woman in the household. She brought boiling water from the stove inside the kiiz yi and sprinkled the wool - a step that releases the lanolin and helps the fibres mesh together. The reed mat with the layers of wool was then rolled up carefully and secured with rope. It was then rolled for two hours. The senior woman participated for a while, demonstrating to the girls how to push and tug at the rolled-up reed mat, after which her place was then taken by a young woman.

Instructive comments were made and adjustments to individuals' actions were worked out in the process, as the felt was rolled: 'Sit like this', 'Pull your sleeves down', 'You are slowing us down'. The reed mat was then unrolled and the felt rolled up again without the reed mat, and rolled for a while longer (photo 6). The whole process, from beating to rolling, lasted from morning to evening. The longer it is 'rolled', the denser and more durable the resulting felt. Finally, the piece was left to dry in the sun (on felt making see also Batchuluun 2003, Bunn 2010, Burkett 1979, Mullins 2009). 


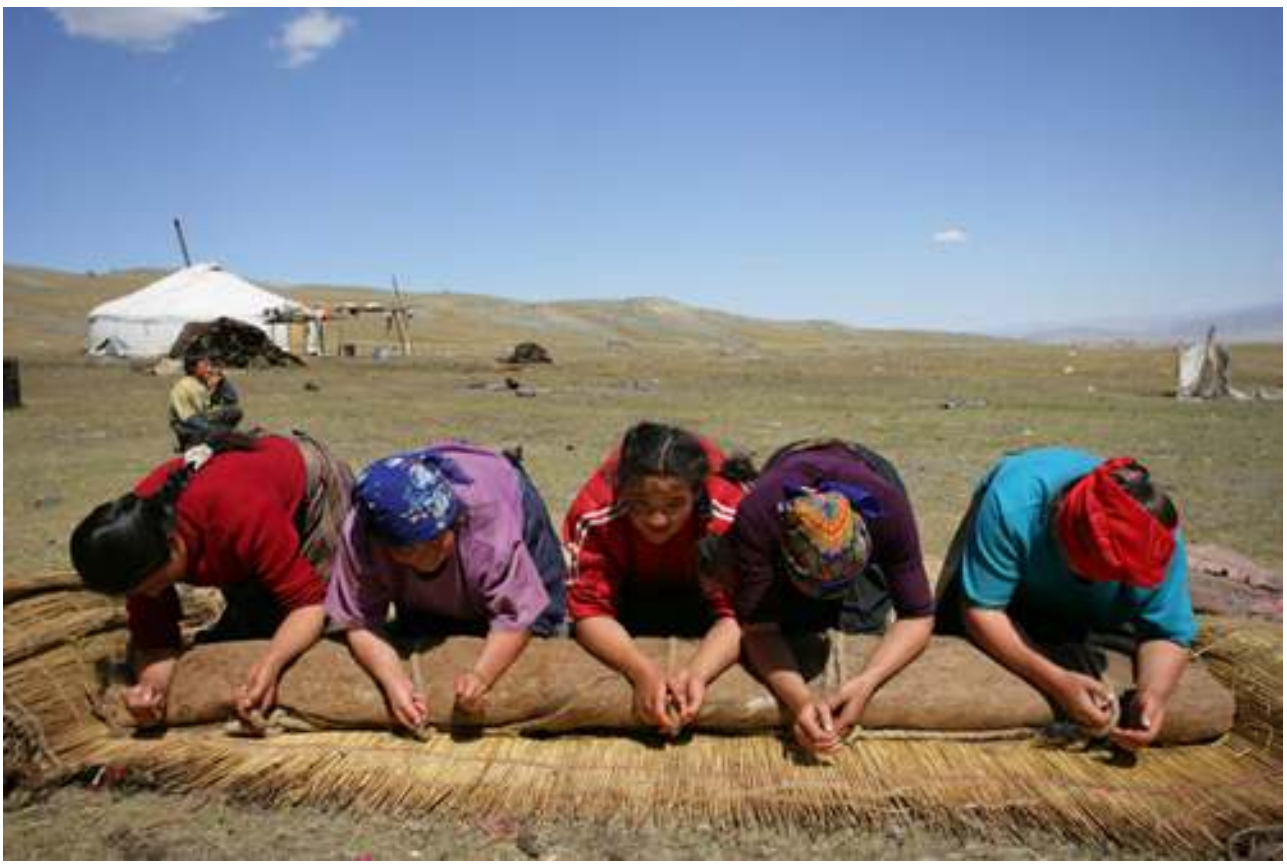

Photo by Antoine de Changy

34 Felt carpets (Kz. sürmaq) are made of two layers of felt: one plain bottom layer which can be made of the 'coarser' type of felt from the winter wool, and one top layer that is usually composed of two (or several) cut-out pieces assembled mosaic-style (photo 7), or a single piece that has been decorated with other bought fabric, for instance velvet, using an appliqué technique. Camel wool thread is used to sew and quilt these carpets. Camel wool makes for a strong thread and is spun either on a handheld spindle or by hand (photo 8). Many families have one or two camels, and only a few camels yield enough wool for spinning thread (or yarn for knitting), the wool being cut in late spring or summer when the animal moults. Camel wool thread (Kz. shuda jip) is particularly sturdy as the wool fibres are long, and indeed this thread effectively holds together the two layers and the cut out mosaic pieces in felt carpets (on felt carpet techniques see also Chabros 1988, Farkas 1995, Portisch 2010, Rona-Tas 1963). 
Photo 7. The sections of a mosaic-style sürmaq before being joined together

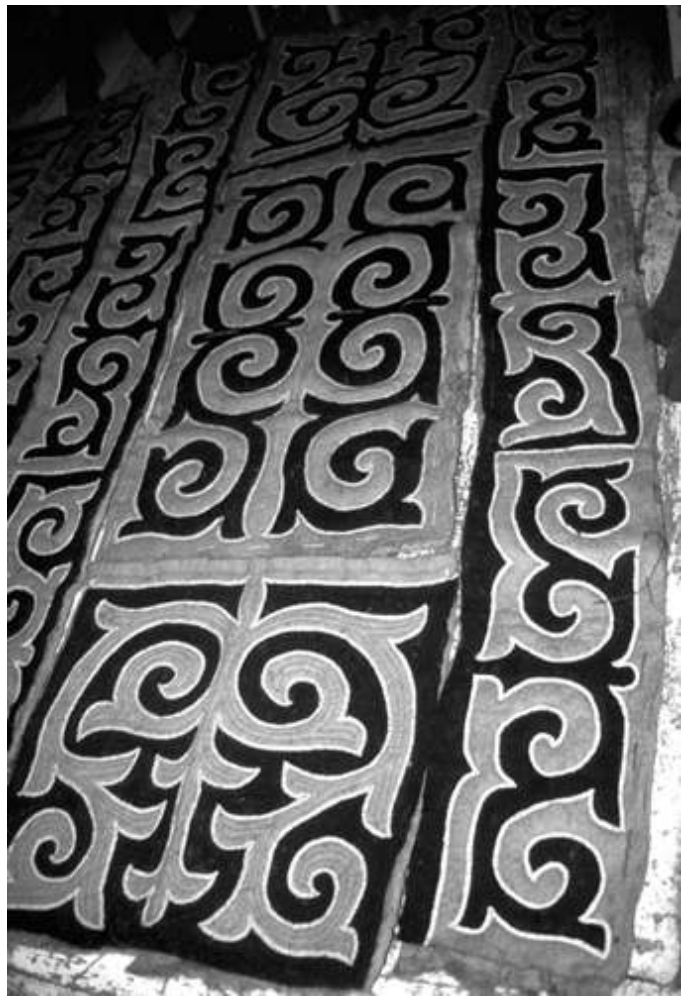

Photo by Anna Portisch

Photo 8. Hand spinning camel wool thread

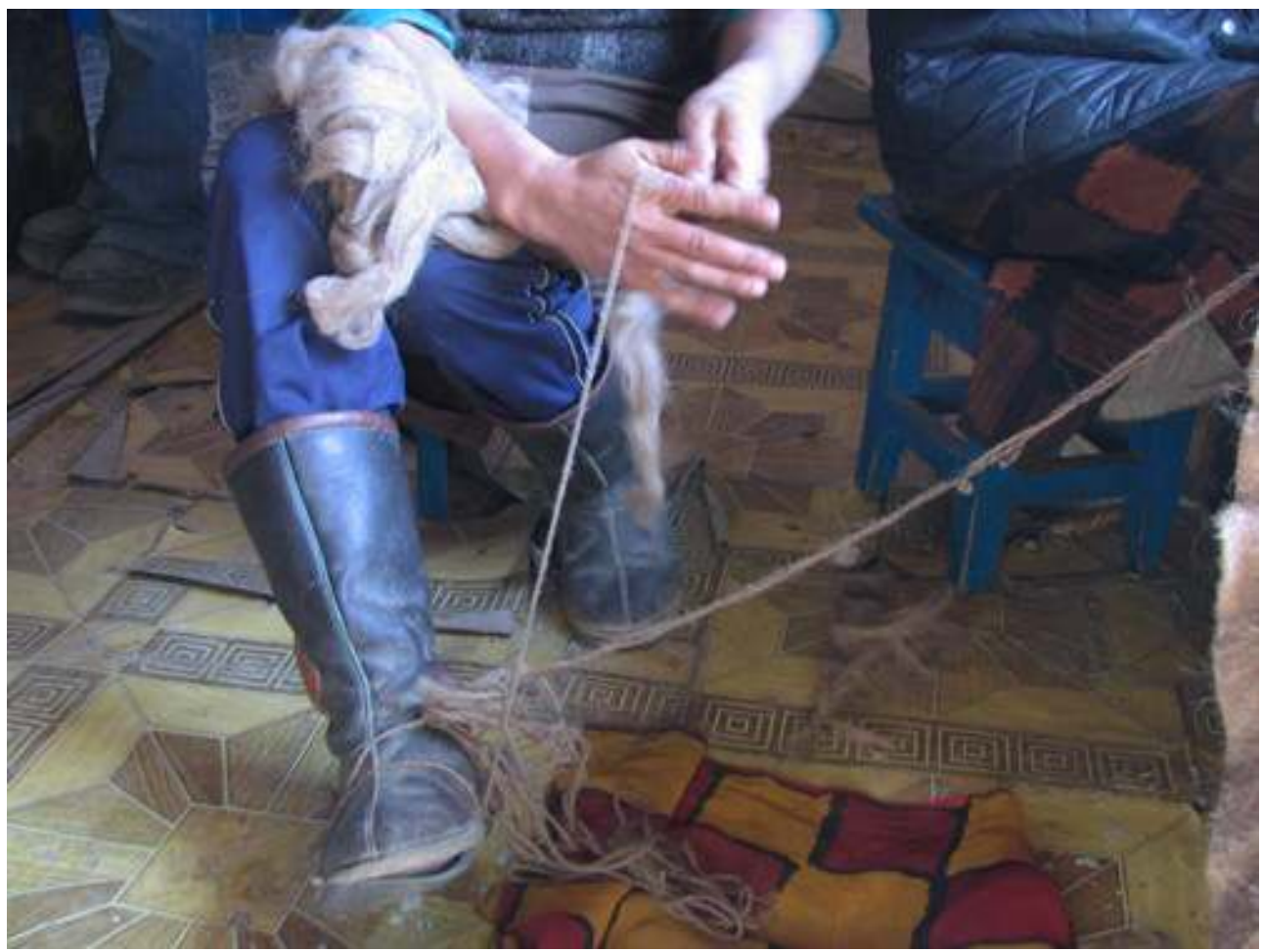

Photo by Anna Portisch 
With home-spun yarn and bought felt and fabric, Aizhan made two felt carpets in the course of the winter. She complained about the quality of the felt, which had not been made in her own household, and decided to use factory-made carpet fabric for the top layer, thus concealing the coarser, poor-quality felt (this type of bought carpet fabric can be seen in the two sürmaq in photo 9. In contrast, the small section of a third sürmaq seen in the top right hand corner is made of felt). The carpet material, which was sold at the market in Ölgii (imported from China), was intended to be used as it was, rolled out on the floor, but Aizhan proceeded to cut out a pattern to be sewn together in mosaic style, just as one would with a carpet made entirely of felt. The bottom felt layer would still serve to insulate from the cold floor, and would make for a thick and comfortable carpet, but would not be seen under the top layer.

Photo 9. Factory-made fabric used to make the top layer of a felt carpet (sürmaq)

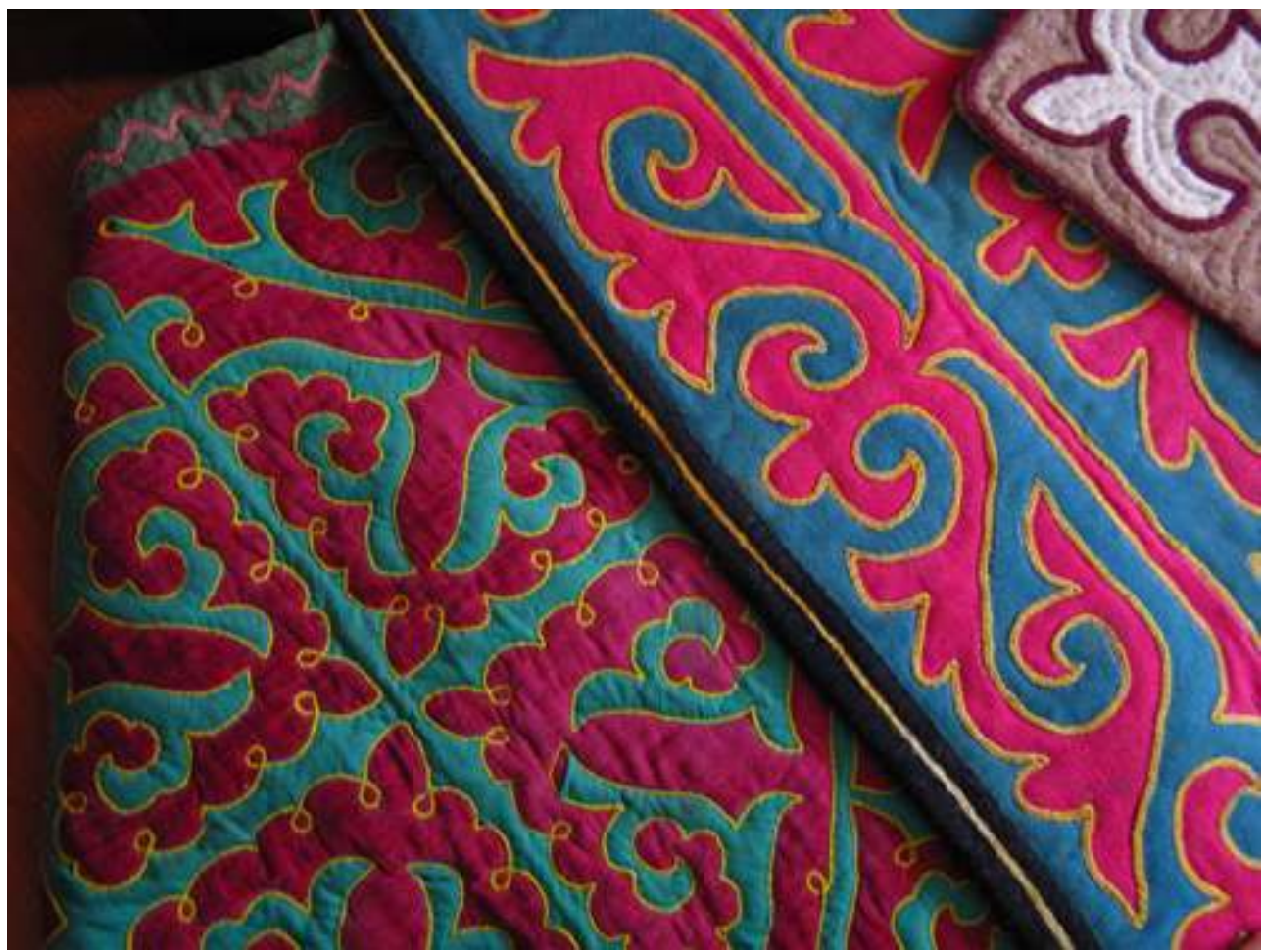

Photo by Anna Portisch preparing felt, are collaborative practices that require the help of half a dozen people and are done in summer when it is warm and therefore possible to work outside. Once the materials have been prepared, sewing and quilting carpets and other artefacts can be done in the course of the winter by a single craftswoman. Nevertheless, many women often contribute to the process. Women enlist the help of their daughters and other junior female household members to carry out time-consuming and repetitive tasks such as quilting the felt. On the other hand, particularly skilled craftswomen in the family may be called upon to complete difficult tasks, such as drawing and cutting out a well-proportioned, aesthetically pleasing pattern for a carpet.

Aizhan, with increasing participation from her daughter, made a variety of soft furnishings for the family's summertime yurt and winter house, including large 
embroidered wall hangings, felt carpets and embroidered panels and valances. The felt carpets she made were used for sitting on at tea time and putting up visitors for the night. Aizhan aimed to make at least one new felt carpet each year, both in order to replace the carpets that were beginning to show signs of wear, but also to put aside for Gülnara's future wedding.

In connection with weddings, the bride's family give a number of bundles of gifts to the groom's family. The bride's mother is responsible for assembling the gift set called the tösek oryn (Kz., literally meaning 'bed seat'). This includes several bundles of gifts : one for the groom's parents ; one for each of his siblings and their families ; and a large set of gifts for the newly-married couple that includes most items needed for setting up a home (pots, pans, mirror cabinets, chests and other furniture, and the textiles needed to furnish and decorate the home). Felt carpets are the most important gift in this set and are valued as much as one large domestic animal (a horse, cow, or yak called in Kz. iri qara meaning 'big black'), which, in return, is given by the groom's parents to the mother of the bride. The groom's family also provides the couple with a yurt if possible, or provides them with accommodation. The couple are thus able to set up home.

Often those women considered the best craftswomen in the family contribute to making the textiles for the newly wedded couple. These textiles are a display of generosity, but also a testament to the skills and creativity of the women in the bride's family. By extension, they are demonstrations of the 'creative lineage' of the bride. They showcase the skills of her teachers, and thus to some extent can be read as indicators of her own abilities or potential. In a similar sense, the skills and aptitudes she displays as a daughter-in-law (Kz. kelin), in carrying out daily household tasks are also seen as a reflection of her upbringing and how well her parents (and particularly her mother) have instilled desirable skills and attitudes in her.

40 A wife is responsible for decorating the home, and a beautifully decorated, clean and tidy home is often seen as a sign of a hard working and talented wife. It is of course also a material expression of a relatively affluent household, with enough 'living resources' to make their own good-quality felt, camel wool thread and other artefacts for the yurt ; and the ability to buy various materials such as velvet and brightly coloured yarn (for making woven yurt straps) and thread (for embroidery). On the other hand, the experimentation with new materials, such as Aizhan's use of carpet fabric, was a practical solution to the lack of wool for felt making, something which reflected the depleted size of their herd of sheep. Often craftswomen in Bayan-Ölgii integrate new or recycled materials in their craft practices because raw materials are not readily available, or bought materials are not available at the market or are too expensive to buy.

41 Women have worked in this way in the past and continue to do so: during the state socialist period, it was often hard to find coloured thread for embroidery and women would extract thread from other, existing fabric to use in their embroidered pieces. Today, nylon thread from old flour bags is used to loosely stitch together felt carpets. An old woollen hat may be unravelled and the yarn 'recycled' for use on the selvedge of a carpet when the home-spun yarn has run out. Often new ways of working and styles of decoration come about through such experimentation. Old veterinary syringes, for instance, are adapted and used to create a 'fluffy' kind of embroidery (Kz. tuqty keste) which is associated with a new decorative style in wall hangings (photo 10). Women use 
materials and resources in often unexpected ways, and in addition use their skills to exploit what commercial opportunities there may be.

Photo 10. Wall hanging in 'fluffy' embroidered style (tuqty keste), for sale at Ölgii market

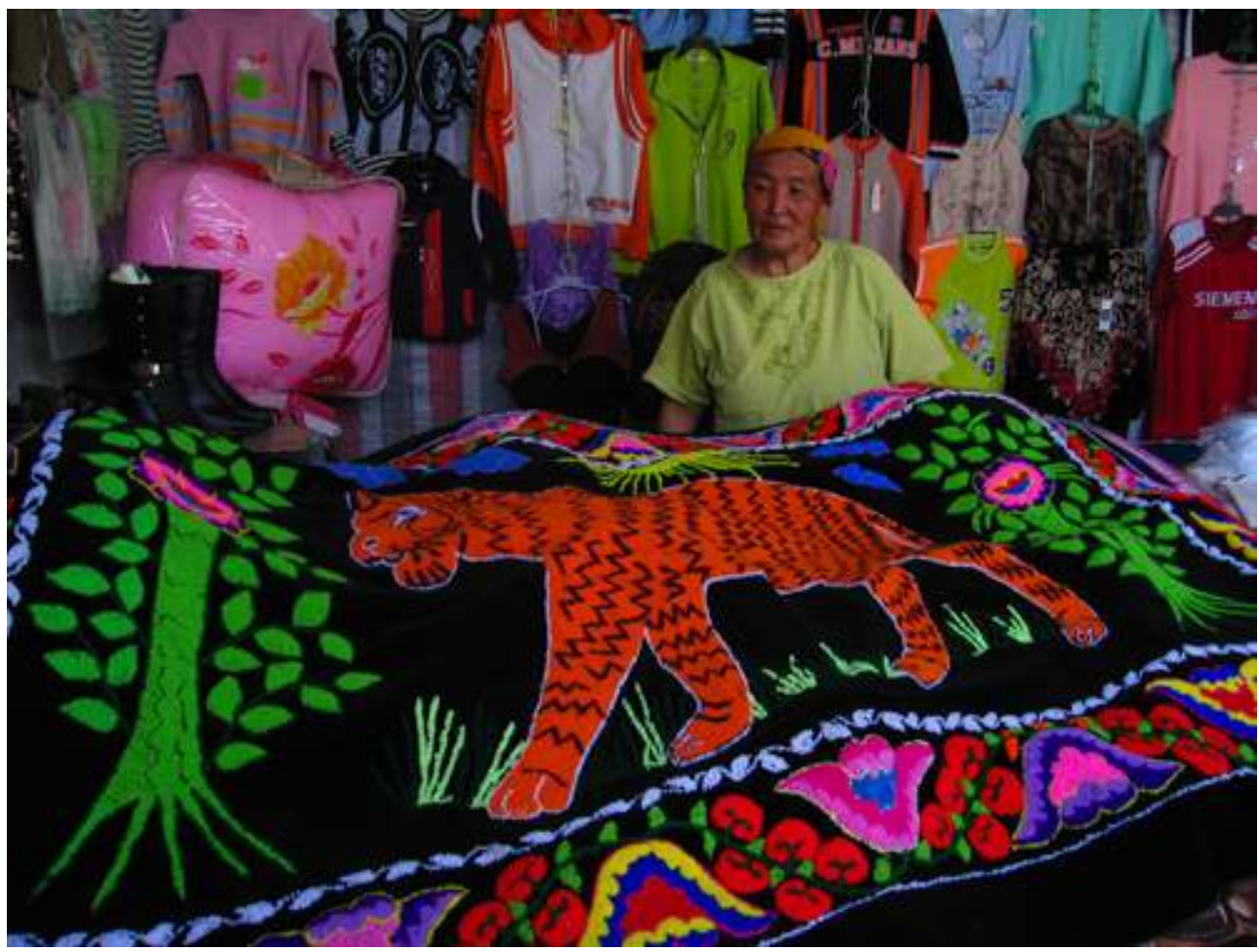

Photo by Anna Portisch

\section{Commercial opportunities}

Goats are combed for their hair in late spring or early summer. The hair is sold at the market in Ölgii to traders, who transport the hair to processing plants in the capital or elsewhere (a large proportion of raw cashmere is also sent abroad for processing, see El Benni \& Reviron 2009, p. 20 ; see also Finke 2003a, p. 212). In 2005, the price paid at Ölgii market by middlemen for one kilo of goat's hair was 20000 , at the time equivalent of ten pounds. Goat's hair is not used for domestic purposes, as this requires the hair to first be sorted (removing dirt) and then 'dehaired' (an industrial process that separates the coarse outer guard hair from the finer cashmere 'down') (see Kerven et al. 2002, p. 25), after which it can be spun for the production of cashmere products.

household artefacts made from wool and hair, such as felt carpets made for the home, may also be sold at the market, either because these are considered old and faded and new carpets are being made to replace them ; for lack of funds; or because a family is moving to Kazakhstan and cannot bring all their possessions with them (see Diener 2009 on these migrants). In this case, the textiles are normally sold to tourists or foreigners and not to other Kazakhs, who are unlikely to furnish their own homes or give as presents, 'home-made' textiles that have not been made in the family'.

Many women in Bayan-Ölgii have also taken up producing felt and embroidered artefacts for sale through crafts shops aimed at tourists in Ölgii, or through charity 
organisations or NGOs working in the area, such as the one which Aizhan had become a member of. Aizhan used the same embroidery techniques in making the handbags and pillow covers for the co-operative as she did in making embroidered wall hangings and panels for her own home. The same tools, a small hooked needle (Kz. biz) and a metal frame for stretching out the fabric, were also used (photo 11). The patterns she drew and embroidered were Kazakh patterns, although these were reproduced at a smaller scale for the craft co-operative. The colours were deemed appropriate for western tastes and differed from Kazakh colour combinations and preferences. The project sought to enable its members to sell products which they could make using their existing skills in domestic textile production, and the tools they already had at their disposal.

Photo 11. Wall hanging being embroidered with a hooked needle (biz)

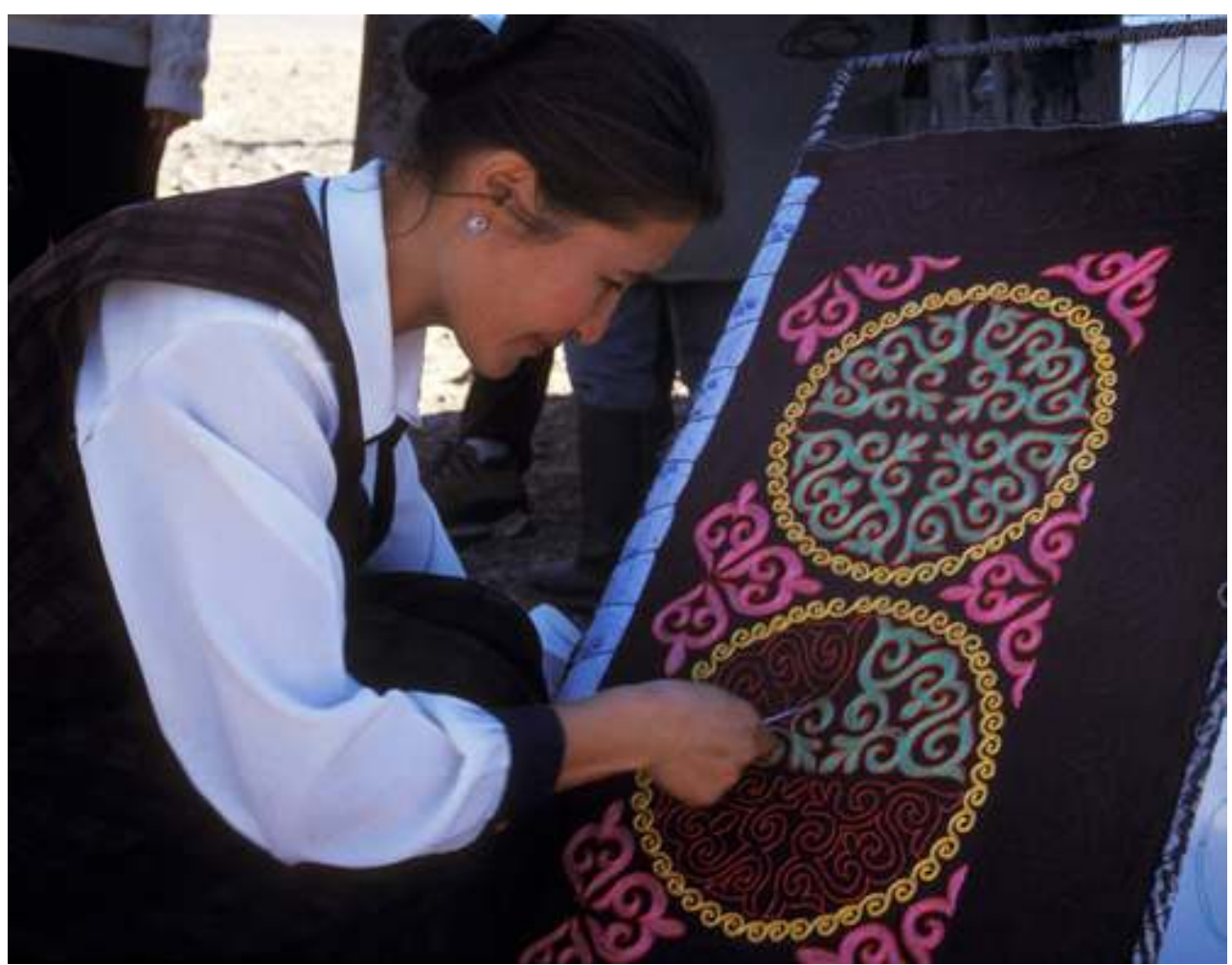

Photo by Anna Portisch

Moreover, in a village of some 200 households, the co-operative offered a unique local opportunity for paid employment to the dozen women involved. The village was not well connected with the rest of the province. The only formal jobs in the vicinity were at the school, where Bolat worked. Those families with members working at the school also relied on herds of domestic animals for meat and dairy products. In the face of increasingly frequent climatic hardship, inflation, and a scarcity of economic opportunities, the craft co-operative thus offered Aizhan a means of sustaining the family. 


\section{Conclusion} practices. The women who were members of the craft co-operative tended to work within the close family on their pieces. In a village comprising of some 200 households, not all women were able to become members of the co-operative, which itself had limited space and resources at its disposal. The project may thus inadvertently have encouraged a more competitive and atomized way of working (see also Finke 2004a, p. 406). The new economic order thus potentially affects the social life and productive relations between relatives and villagers. Nevertheless, in the absence of substantial government or foreign investment in the province, charity and NGO-led projects provide a much-needed opportunity for using existing skills and local raw materials.

\section{BIBLIOGRAPHIE}

Badarch, D., Batsukh, N. \& Batmunkh, S.

2003 The impact of industrialization in Mongolia, in D. Badarch, R. A. Zilinskas \& P. J. Balint (ed.)

Mongolia today: science, culture, environment and development (London, RoutledgeCurzon), pp. 3-20.

Batchuluun, L.

2003 Felt art of the Mongols (Ulaanbaatar, Institute of Arts and Culture, Mongolian University of Arts and Culture), $291 \mathrm{p}$.

Bunn, S.

2010 Nomadic felts : artistic traditions in world cultures (London, British Museum Press). 
Burkett, M. E.

1979 The art of the felt maker (Kendal, Abbot Hall Art Gallery), 111 p.

Chabros, K.

1988 Quilted ornamentation on Mongol felts, Central Asiatic Journal 32(1), pp. 34-60.

de Changy, A. \& Antomarchi-Lamé, C.

2008 L'appel de la steppe, 52 min., colour, French (www.phileasfrogs.com/confdmx.html).

Daukeyeva, S.

2010Dombra performance, meaning and memory among Mongolian Kazakhs. Thesis (Ph.D.)

(School of Oriental and African Studies, London).

Diener, A.

2009 One homeland or two? The nationalization and transnationalization of Mongolia's Kazakhs

(Stanford, CA, Stanford University Press).

El Benni, N. \& Reviron

2009 (March) Geographical indicators : review of seven case-studies world wide. NCCR trade regulation Swiss national centre of competence in research, working paper no. 2009/15. Accessed from http://phase1.nccr-trade.org/images/stories/publications/IP5/GI_Case-studies_2009.pdf, 26 Nov. 2010.

Farkas, 0 .

1995 The Kazakh syrmak : quilting, mosaic and appliqué techniques applied onFelt, Echoes : the Journal of the International Feltmakers Association 39, pp. 12-13.

Finke, $\mathrm{P}$.

2003a Does privatisation mean commoditisation? Market exchange, barter, and gift giving in post-socialist Mongolia, Research in Economic Anthropology 22, issue on 'Anthropological perspectives on economic development and integration', pp. 199-223.

$2003 \mathrm{~b}$ Le pastoralisme dans l'ouest de la Mongolie : contraintes, motivations et variations, Cahiers d'Asie centrale 11/12 'Les Montagnards d'Asie Centrale' (Tashkent/Aix-en-Provence, IFEAC), pp. 245-265.

2004 Contemporary pastoralism in Central Asia, in G. Rasuly-Paleczek et J. Katsching (ed.), Central Asia on display : proceedings of the VII conference of the European society for Central Asian studies 1 (Wien, LIT VERLAG), pp. 397-410.

Goyal, H. D.

1999 A development perspective on Mongolia, Asian Survey 39(4), pp. 633-655.

Kämälashuly, B.

2005 Qazaqtyng baiyrghy baspahalary, üi-zhihazdary, ylttyq kiim-keshek, ydys-ayaq, as-susyn, tamaqtaghamdaryna qatysty salt-dästurler [Traditions and customs related to indigenous Kazakh dwellings, interiors, national costume, household utensils, food, drink and dishes] (Bayan-ölgii, Mongolia).

Kerven, C., Russel, A. \& Laker, J.

2002 Potential for increasing producers' income from wool, fibre and pelts in Central Asia, Socioeconomics and Policy Research Working Paper 45 (Kenya/Aberdeen, International Livestock Research Institute/The Macaulay Institute).

Lacaze, G.

2005 Ballade du négociant (France) 59' DVD, colour, French. 
Marsh, P. K.

2009 The horse-head fiddle and the cosmopolitan reimagination of tradition in Mongolia (New York, Routledge).

Mullins, W.

2009 Felt (Oxford, Berg).

NSO (National Statistical Office of Mongolia)

20012000 Population and Housing Survey (Ulaanbaatar, Mongolia).

2008 Livestock 2007 (Ulaanbaatar, Mongolia).

Pegg, C.

2001 Mongolian music, dance and oral narrative : performing diverse identities (Seattle, University of Washington Press).

Portisch, A. 0 .

2007 Kazakh syrmaq-production in western Mongolia : learning and skill in a domestic craft tradition. Ph.D. Thesis (School of Oriental and African Studies University of London).

2010 The craft of skilful learning : Kazakh women's everyday craft practices in western Mongolia, Journal of the Royal Anthropological Institute, Special Issue 2010 'Making Knowledge', pp. 62-79.

Rona-Tas, A.

1963 Felt-making in Mongolia, Acta Orientalia Scientiarum Hungariarum 16(2), pp. 199-215.

Sanders, A. J. K.

1993 The Turkic peoples of Mongolia, in M. Bainbridge (ed.), The Turkic peoples of the world (London, Kegan Paul).

Siura, H. \& Swift, J.

2002 Drought and zud but no famine (yet) in the Mongolian herding economy, IDS Bulletin 33(4), pp. 88-97.

Sneath, D.

1999 Mobility, technology, and decollectivisation of pastoralism in Mongolia, in S. Kotkin \& B. A. Elleman (ed.), Mongolia in the twentieth century : landlocked cosmopolitan (New York/London, M. E. Sharpe), pp. 223-236.

2002 Producer groups and the decollectivization of the Mongolian pastoral economy, in J. Heyer, F. Streart \& R. Thorp (ed.), Group behaviour and development : is the market destroying cooperation? (Oxford, University Press), pp. 161-184.

2003 Lost in the post : technologies of imagination, and the Soviet legacy in post-socialist Mongolia, Inner Asia 5, pp. 39-52.

2004 Property regimes and sociotechnical systems : rights over land in Mongolia's "Age of the Market", in K. Verdery et C. Humphrey (ed.), Property in question : value transformation in the global economy (Oxford/New York, Berg), pp. 161-182.

Vitebsky, P.

2005 Reindeer people : living with animals and spirits in Siberia (London/New York, Harper Perennial). Willerslev, R.

2004 Not animal, not not-animal : hunting, imitation and empathetic knowledge among the Siberian Yukaghirs, Journal of the Royal Anthropological Institute 10, pp. 629-652. 


\section{NOTES}

1. Cattle, yak and hybrids of cattle and yak: Kazakhs in Bayan-Ölgii keep both cattle, yaks and hybrids. A hybrid between cattle (Kz. sier) and yak (Kz. sarlyk) is called a kainik. (Mg. hainag). There is apparently no general preference for crossbreeding male or female yak with female or male cattle. In terms of quantities of milk produced, the kainik produces most milk; cows produce less milk, and yaks produce the smallest quantity. However, it is thought that yak's milk is 'thicker' and of the highest nutritional value, cow's milk is less nutritionally valuable, and kainik milk is 'watery' and least valuable.

2. Knitting : this is a relatively recent practice in Bayan-Ölgii. It became popular in the province in the 1990s and has since also become part of home-economics lessons in some schools (personal communication, former teacher at Ten Year School, Ulaanhus, Bulbul Ustav, Feb. 2011.

3. Horse hair : hair deriving from horses in northern or cold climates is thought superior in the international production of violin bows (as such hair apparently provides more friction). None of my informants in Bayan-ölgii, however, sold horse hair, probably because the price offered was too low. The strings on the Mongolian instrument, the morin huur, are made of hairs from horses' tails (or nylon thread) and the bow is made from horses' hair. The strings and bows of the Kazakh instrument, the kobyz, are also made of horse hair (this instrument is more frequently used in Kazakhstan itself) (for a discussion of musical traditions in Mongolia see Daukeyeva 2010, Marsh 2009, Pegg 2001).

4. Cost of petrol : during the state-socialist period petrol was subsidized. Fuel prices were liberalized under the new government led by the Democratic Party elected in 1996 (Sneath 2002, p. 194).

5. Withdrawal from the market: Vitebsky makes a similar point in relation to Eveny reindeer herders in Siberia (2005); as does Willerslev in relation to another Siberian people, the Yukaghir who since the early 1990s have come to rely on hunting and fishing and "... have returned to a predominantly subsistence-based lifestyle" (2004, p. 632).

6. Names : individuals' names have been changed.

7. The Eight Year School : this is a primary school taking pupils up to their eighth school year. Most pupils from the village continue in their ninth and tenth year at the Ten Year School in the district centre (together with those pupils who have attended the Ten Year school from year one). Until 2006, ten years of schooling was mandatory, but a national restructuring of the primary and secondary educational system has since made eleven and subsequently twelve years of schooling compulsory.

8. Summer location: how far people move between seasonal settlements depends on their economic situation, reflected in their herd size, as well as other considerations such as variations in the quality of pasture and climatic conditions. People with large herds, say of 200-300 sheep and goats, may move several hundred kilometres between fixed winter and spring houses and summer settlement areas (where they set up their yurt) (see de Changy \& Antomarchi-Lamé 2008 for a film describing such a move from winter to spring pasture).

9. Home-made or bought textiles : factory-made pile carpets with motifs of mountain goats or running horses are well liked and often hang next to embroidered wall hangings in the yurt. Pile carpets with sürmaq patterns could be bought at the market in ölgii in 2008 and were becoming popular as wedding gifts. 


\section{RÉSUMÉS}

Cet article traite des aspects sociaux et économiques de l'utilisation de la laine et des poils d'animaux domestiques (moutons, chèvres, vaches, yaks ou hybrides, chevaux et chameaux) chez les Kazakh de la province de Bajan-Ölgij (Bayan Ölgii). Cette province de l'extrême ouest de la Mongolie est essentiellement peuplée de Kazakh, qui représentent la plus grande minorité du pays et qui se concentrent dans les provinces occidentales. L'article commence par replacer les pratiques économiques et domestiques des foyers kazakhs dans le contexte historique récent. Les activités économiques au cours de la période ayant précédé l'effondrement de l'Union Soviétique sont brièvement décrites. L'article aborde ensuite les usages domestiques actuels de la laine et des poils, ainsi que la vie sociale autour de ces usages et des procédés de fabrication dans un village isolé de Bajan-Ölgij. Cet article explore comment les différents usages de la laine et des poils reflètent la situation économique et sociale du foyer domestique sur les plans économiques et sociaux, ainsi que des processus socio-économiques plus larges.

This article considers social and economic aspects of the uses of wool and hair derived from domestic animals (sheep, goats, cows, yaks or crossbreeds, horses and camels) amongst the Kazakh population living in the western-most Mongolian province, Bayan-Ölgii. This province is mainly populated by Kazakhs, who form the country's largest minority and are concentrated in the western provinces. The article begins by contextualising Kazakh households' economic and domestic practices in the context of the recent past. It briefly outlines the framework for economic activity during the period leading up to the dissolution of the Soviet Union. It goes on to look at domestic uses of wool and hair today, and the social life around such uses and production routines in a small village in Bayan-ölgii. The article thus explores how the uses of wool and hair from domestic animals are practices which reflect the economic and social situation of the household as well as wider societal processes.

\section{INDEX}

Index géographique: Mongolie

Mots-clés : animaux domestiques, laine, poils, économie domestique

Keywords : domestic animals, wool, hair, economic conditions

nomsmotscles Kazakh

\section{AUTEUR}

\section{ANNA O. PORTISCH}

Anna O. Portisch is a postdoctoral associate at SOAS, where she completed her doctoral research in 2007. This research explores learning processes and skill-based knowledge in Kazakh women's domestic textile production. The research is based on a year's fieldwork in Bayan-Ölgii, western Mongolia. In 2009, she curated an exhibition on Kazakh textiles for the Brunei Gallery, SOAS, and was an ESRC postdoctoral fellow at Brunel University.

Publications : 2010 The craft of skilful learning : Kazakh women's everyday craft practices in western Mongolia, Journal of the Royal Anthropological Institute, Special Issue 'Making Knowledge', pp. 62-79.

2009 Techniques as a window onto learning : Kazakh women's domestic textile production in 
western Mongolia, Journal of Material Culture 14(4), pp. 471-193.

ap48@soas.ac.uk 